AGRICULTURE AND BIOLOGY JOURNAL OF NORTH AMERICA

ISSN Print: 2151-7517, ISSN Online: 2151-7525, doi:10.5251/abjna.2011.2.7.1135.1142

(C) 2011, ScienceHu $\beta$, http://www.scihub.org/ABJNA

\title{
Production, purification and crystallization of an alkaline protease from Aspergillus tamarii[EF661565.1].
}

\author{
Namrata Sharma ${ }^{1}$ and Kantishree De $^{2}$ \\ 1. Department of Biochemistry, Mata Gujri, Mahila Mahavidyalaya, Jabalpur (M.P.) 482002 \\ e-mail address-dnamratas@rediffmail.com \\ ${ }^{2}$ Department of Biological Sciences, Rani Durgawati University, Jabalpur
}

\begin{abstract}
An extracellular alkaline serine protease has been purified from a strain of Aspergillus tamarii [EF661565.1] to homogeneity, by ammonium sulphate precipitation and chromatography on CMCellulose. Its molecular weight estimated by SDS-PAGE was $63 \mathrm{kDa}$. Maximum protease activity was observed at $\mathrm{pH} 8-9$ and $60^{\circ} \mathrm{C}$ temperature. The protease was strongly inhibited by PMSF. The activity of enzyme was enhanced by $\mathrm{Zn}^{+2}$ and $\mathrm{Mg}^{+2}$. A strong inhibitory effect was observed in the presence of $\mathrm{Hg}^{+2}, \mathrm{Co}^{+2}$ and $\mathrm{Ca}^{+2}$ ion. The crystallization of purified enzyme was performed by ammonium sulphate.
\end{abstract}

Keywords- Aspergillus tamarii, serine protease, temperature, $\mathrm{pH}$.

\section{INTRODUCTION}

Proteases are among the most important commercial enzymes, and are used especially in the food processing, detergents and other chemical and pharmaceutical industries (Chakrabarti et al.,2000, Kim et al.,2005, Lin et al., 2007). Proteases have also been used in the recovery of silver from photographic plates (Fugiwara et al., 1991) and peptide synthesis (Cervosky, 1992). Microbes from varied habitants have been examined by many researchers to obtain industrially suitable proteases (Ward et al.,1983,Outrup and COL Boye 1990,Gajju et al., 1996,Sen and Satyanarayana, 1993 ). Molds of the genera Aspergillus, Penicillium and Rhizopus are especially useful for producing proteases, as several species of these genera are generally regarded as safe (Sandhya et al., 2005).

In recent years, several proteases from different species of Aspergillus have been isolated and characterized in detail (Hayashi et al.,1970, Turkova et al., 1971, Tunga et al., 2003) but variations in molecular weights of these Aspergillus proteases have been reported. Thus, it may be of interest from a genetic and taxonomic viewpoint to compare the properties of proteases produced by the members of genus Aspergillus (Charles et al., 2008). Also the industrial demand of proteolytic enzymes stimulate the search of new enzyme sources for extended range of applications. Recently, large proportions of commercial proteasse are available from Bacillus sp. (Kazan et al.,2005, Miyaji et al.,2006) although the potential use of several fungal sources is now being increasingly realized (Phadatare et al., 1993).

In the present study, protease produced by Aspergillus tamarii [EF661565.1] has been purified, crystallized and characterized to exploit its benefit in industries.

\section{MATERIALS AND METHODS}

Microorganism and growth conditions- Aspergillus tamarii [EF661565.1] was isolated from soil samples at Jabalpur, India, on Potato Dextrose Agar Medium and identified at molecular level from Agharkar Research Institute Pune, India. The fungus was grown in Erlenmeyer flasks containing $250 \mathrm{ml}$ of Yeast Extract broth and maintained at $28^{\circ} \mathrm{C}$ under a constant shaking condition (150 rpm). At the end of the incubation period ( $4^{\text {th }}$ day), the culture was taken and centrifuged at $10,000 \mathrm{rpm}$ for $10 \mathrm{~min}$ at $4^{\circ} \mathrm{C}$ to remove the unwanted mycelia. The crude enzyme was recovered in the supernatant.

Enzyme activity assay: Protease activity was assayed by the method of Anson (1938).

Protein concentration assay: Protein concentration was measured by the method of Lowry (1951) using Bovine Serum Albumin as the standard.

Influence of Protein substrates on extracellular protease production: A.tamarii [EF661565.1] was grown on four different protein substrates. For this, Yeast Extract Agar medium was supplemented with $1 \%(w / v)$ of gelatin, BSA, casein and hemoglobin as 
substrates in separate sets. $20 \mathrm{ml}$ of medium supplemented with different protein substrates was then poured per plate and allowed to solidify. $A$. tamarii [EF661565.1] inoculum was placed in the center of the agar plate. After inoculation, the plates were incubated at $28^{\circ} \mathrm{C}$. Extracellular protease detection was done after staining with $0.1 \%$ amido black (Vermelho et al., 1996) for 1 hour at $28^{\circ} \mathrm{C}$. Regions of enzyme activity were detected as clear areas, indicating that hydrolysis of substrates had occurred.

Influence of carbon sources on the expression of extracellular protease production: For evaluation of effect of carbon source on enzyme production in culture media, six different carbon sources including sucrose, glucose, strach, fructose, glycerol and trisodium citrate $(2 \% \mathrm{w} / \mathrm{v})$ were added to Yeast Extract broth. After $96 \mathrm{~h}$ incubation at $28^{\circ} \mathrm{C}$, the crude extract was analyzed for protease activity.

Influence of nitrogen sources on extracellular protease production: For evaluation of effect of nitrogen source on enzyme production in culture media, seven different nitrogen sources including Yeast extract, glutamic acid, ammonium sulphate, peptone, ammonium nitrate and potassium nitrate $(0.5 \%)$ were added to culture broth containing $\mathrm{KCl}, 2 \%$; Casein, 1\%; Sucrose, $2 \%$. After $96 \mathrm{~h}$ incubation at $28^{\circ} \mathrm{C}$, crude extract was analyzed for protease activity.

Purification of protease: All operations were performed at $4^{0} \mathrm{C}$. The enzyme was precipitated from crude extract by the gradual addition of solid ammonium sulphate with gentle stirring to $75 \%$ saturation and the pellet was collected by centrifugation at $10,000 \mathrm{rpm}$ for $10 \mathrm{~min}$. The protein pellet obtained after saturation was dissolved in $0.1 \mathrm{M}$ Tris- $\mathrm{HCl}$ buffer, and loaded on to prepacked desalting column of cross linked dextran with epichlorohydrin, equilibrated with Tris- $\mathrm{HCl}$ buffer, $\mathrm{pH}$ 7.8. The protease was eluted at $1.0 \mathrm{M} \mathrm{NaCl}$ concentration. The desalted sample was analyzed further.

CM- Cellulose Column chromatography: The desalted sample was then applied to CM-cellulose column $(8 \times 1.5 \mathrm{~cm})$ previously equilibrated with Tris$\mathrm{HCl}$ buffer $\mathrm{pH} 7.5$.

The enzyme was eluted with the same buffer. Fractions showing protease activity were pooled and checked for homogeneity and to study the enzymatic properties.
Electrophoretic Method: The purity of protease was then analyzed by $10 \%$ SDS polyacrylamide gel electrophoresis and staining with Coomassie Brilliant Blue $(2.5 \mathrm{~g} /$ lit in $200 \mathrm{~g} / \mathrm{lit}$ TCA).

Effect of $\mathrm{pH}$ and temperature on protease activity: The optimum $\mathrm{pH}$ for activity of the purified protease was investigated by measurements at $37^{\circ} \mathrm{C}$ in buffers of various $\mathrm{pH}$. The $\mathrm{pH}$ was adjusted using the following buffers - phosphate buffer $(\mathrm{pH}$ 7.0); Tris$\mathrm{HCl}$ buffer $(\mathrm{pH} 8.0)$, glycine $-\mathrm{NaOH}$ buffer $(\mathrm{pH} 9.0-$ 11.0). The effect of temperature on its activity was investigated keeping $\mathrm{pH} 7.5$ constant. Protease activities were assayed at standard assay conditions.

Effect of protease inhibitors: Protease type was determined by employing the following inhibitors: $p$ chloromercuribenzoic acid (pCMB), ethylenediaminetetraacetic acid (EDTA), phenylmethylsulfonylfluoride $\quad$ (PMSF), $\quad \beta$ mercaptoethanol and iodoacetate (IAA). Protease was preincubated with each inhibitor $(5 \mathrm{mM})$ in 100 $\mathrm{mM}$ Tris- $\mathrm{HCl}$ buffer $(\mathrm{pH} 8.0)$ for 30 minutes at $37^{\circ} \mathrm{C}$. The control was preincubated without any inhibitor and the residual activity was measured.

Effect of Various metal ions on protease activity : The effect of Metal ions (e.g. $\mathrm{Na}^{+2}, \mathrm{Co}^{+2}, \mathrm{Ca}^{+2}, \mathrm{Cu}^{+}$, $\mathrm{Hg}^{+2}, \mathrm{Zn}^{+2}$ and $\mathrm{Mg}^{+2}$ ) at $5 \mathrm{mM}$ concentration was investigated by adding them to enzyme solution for $30 \mathrm{~min}$ at $37^{\circ} \mathrm{C}$. Relative protease activity was measured by adding the substrate and carrying out the enzyme assay under the optimum conditions.

Crystallization of protease: The purified alkaline protease was crystallized by ammonium sulphate. In this method the salt is added to a concentrated enzyme solution until slight turbidity appears. It is then allowed to stand unagitated and evaporate in order to increase salt concentration very gradually.

\section{RESULTS AND DISCUSSION}

Aspergillus tamari [EF661565.1] hydrolyzed preferentially casein incorporated in Yeast Extract. However, when inoculated in BSA, gelatin and hemoglobin, Yeast Extract medium, a very low extracellular protease production was detected, although increase in colony size was noticed (figure:3).

This study has shown that casein can influence markedly the production of extra cellular protease by Aspergillus tamarii [EF661565.1]. Differences in the ability to utilize different protein substrates may be due to difference in substrate specificities of the enzyme produced (de Gorgi et al., 1985) or may be consequence of parameters known to affect 
extracellular protease production such as $\mathrm{pH}$, medium composition and temperature.

Casein was the most effective protease producing substrate, followed by gelatin, BSA, and hemoglobin. It is possible that casein as a high molecular weight protein, induces an increase in the protein production to degrade the substrate to an available form for utilization by the organism.

The highest protease production was achieved by addition of glycerol among other carbon sources. This observation is in agreement with previous studies which suggest that larger amount of enzyme is synthesized when carbon sources used is poorly utilized for growth purposes (Prasad et al., 1984). When the culture broth was supplemented with glucose, decreased protease production was seen (Table-1). It seems that "catabolite repression" phenomenon, is the best possible explanation for reduction of protease production in the presence of glucose (Glazer and Nikaido,1995). Analogous results are reported in Micrococcus luteus (Vermelho et al., 1996). The addition of glucose $(1 \% \mathrm{w} / \mathrm{v})$ to basal medium reduces alkaline protease production by Bacillus horikoshii to $45 \%$ (Joo et al., 2003). Also, Gessesso et al., (2003) reported that in the presence of glucose in Bacillus nesterkonia sp. AL-20, protease production is suppressed.

The type of nitrogen sources also affect enzyme production. Table-2 shows effects of single and mixed nitrogen sources on protease production. The addition of glutamic acid with Yeast Extract medium increased the production of protease by Aspergillus tamarii [EF661565.1]. The protease activity obtained was $250 \mathrm{U} / \mathrm{ml} / \mathrm{min}$. Moderate to good levels of enzyme activities were obtained when peptone is used as nitrogen source. When various inorganic nitrogen sources were tested for protease production, it was found that protease formation by Aspergillus tamarii [EF661565.1] was repressed. Similar results is obtained by Phadatare et al.,(1993) in Conidiobolus coronatus. They reported the enhancement of protease production in Conidiobolus coronatus by organic nitrogen sources like tryptone, peptone and Yeast Extract.

Organic nitrogen sources have been found to be better nitrogen sources for growth and protease production in some organisms ( Phadatare et al., 1993,Aleksieva et al., 1981) , while inorganic nitrogen sources gave better enzyme yields in other organisms(Sinha and Satyanarayan, 1991).
Protease was purified from culture broth of Aspergillus tamarii [EF661565.1] by the procedure described in materials and methods. A single peak was obtained when the desalted sample was passed through a CM- cellulose column $(8 \times 1.5 \mathrm{~cm})$ with Tris$\mathrm{HCl}$ buffer, $\mathrm{pH}$ 7.5. The steps of purification procedure and recovery of enzyme at each step are presented in Table-3. CM-cellulose fraction showed 26 fold enzyme purification with a specific activity of $11078 \mathrm{U} / \mathrm{mg}$.

The enzyme purity was confirmed by SDS-PAGE which exhibited a single band after ion- exchange chromatography [figure:4] . The enzyme was speculated to be a monomer composed of only one unit. The apparent molecular weight of the purified alkaline protease was estimated to be $63 \mathrm{kDa}$ as measured by SDS-PAGE.

This protease from Aspergillus tamarii [EF661565.1] was characterized. The optimum $\mathrm{pH}$ was found to be between 8-9 (Fig:2), indicating that this enzyme might be the alkaline protease. Similar result are observed in the protease produced by Aspergillus oryzae AWT 20 sp.(Sharma et al., 2006), Bacillus circulans (Jaswal and Kocher, 2007) and Aspergillus clavatus (Celia et al., 2007).

The optimum temperature for protease activity was detrmined by screening temperatures from $20^{\circ}$ to $90^{\circ} \mathrm{C}$ using casein as a substrate dissolved in phosphate buffer at $\mathrm{pH}$ 7.5. The protease showed best activity at $60^{\circ} \mathrm{C}$ but was inactive beyond $80^{\circ} \mathrm{C}$ temperature. Thus optimum temperature of protease activity was $60^{\circ} \mathrm{C}$ (Fig:1). This result also confirmed that the enzyme produced by this Aspergillus tamarii [EF661565.1] was an alkaline protease.

The protease enzyme was completely inhibited by PMSF, a well known inhibitor of serine protease (Table -4), suggesting that this enzyme was a serine protease. Similar results of serine protease inhibition by PMSF, were observed in serine protease produced by $A$. flavus (Hossain et al., 2006), and $A$. oryzae AWT 20 ( Sharma et al., 2006). Gold and Fahrney (1964) also explained that alkaline protease is completely inhibited by PMSF in which PMSF sulfonated essential serine at the active site and resulted in complete loss of activity.

The protease activity was enhanced with an addition of $\mathrm{Zn}^{+2}$ and $\mathrm{Mg}^{+2}$ ion resulting in the relative activity of $120 \%$ and $130 \%$ respectively, suggesting that metal ions had a compatibility with enzyme and protected it against denaturation. Jaswal \& Kocher (2007) reported that the protease produced by 
Bacillus circulans is enhanced by $\mathrm{Zn}^{+2}$. In addition, alkaline protease required a divalent cation like $\mathrm{Cu}^{+2}$. A strong inhibitory effect of $\mathrm{Hg}^{+2} \mathrm{Co}^{+2}$ and $\mathrm{Ca}^{+2}$ ions on protease activity of our strain of Aspergillus tamarii [EF661565.1] was observed. The inhibitory effect of heavy metal ions is well documented in the literature. It is known that mercury ion reacts with protein thiol groups (converting them to mercaptides), as well as with histidine and tryptophan residues(Wellingta et al., 2004).

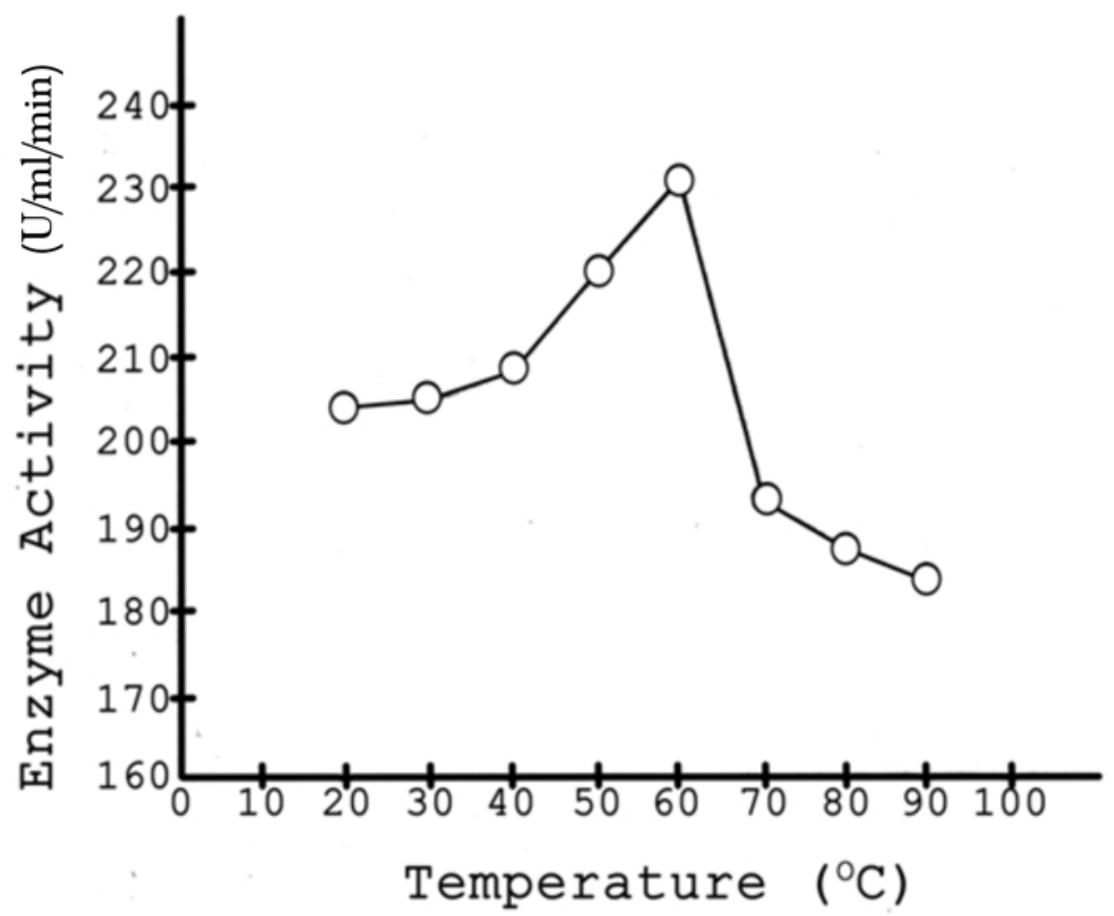

Fig 1- Effect of temperature on Protease Activity from Aspergillus tamarii [EF6615651].

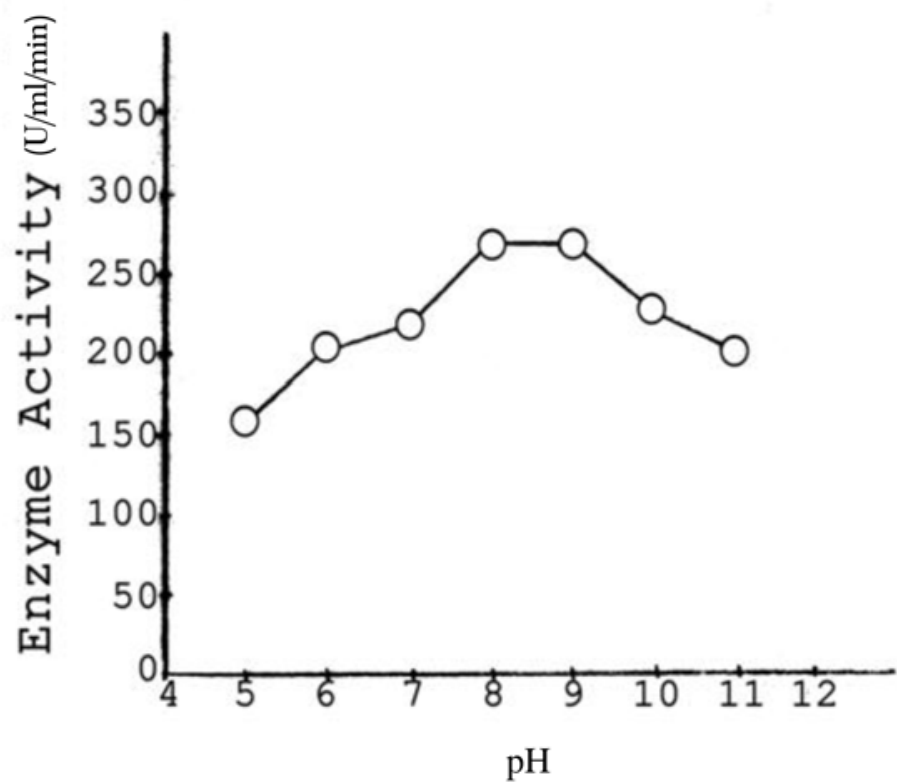

Fig 2- Effect of pH on protease activity from Aspergillus tamarii[ EF661565.1]. 
A.
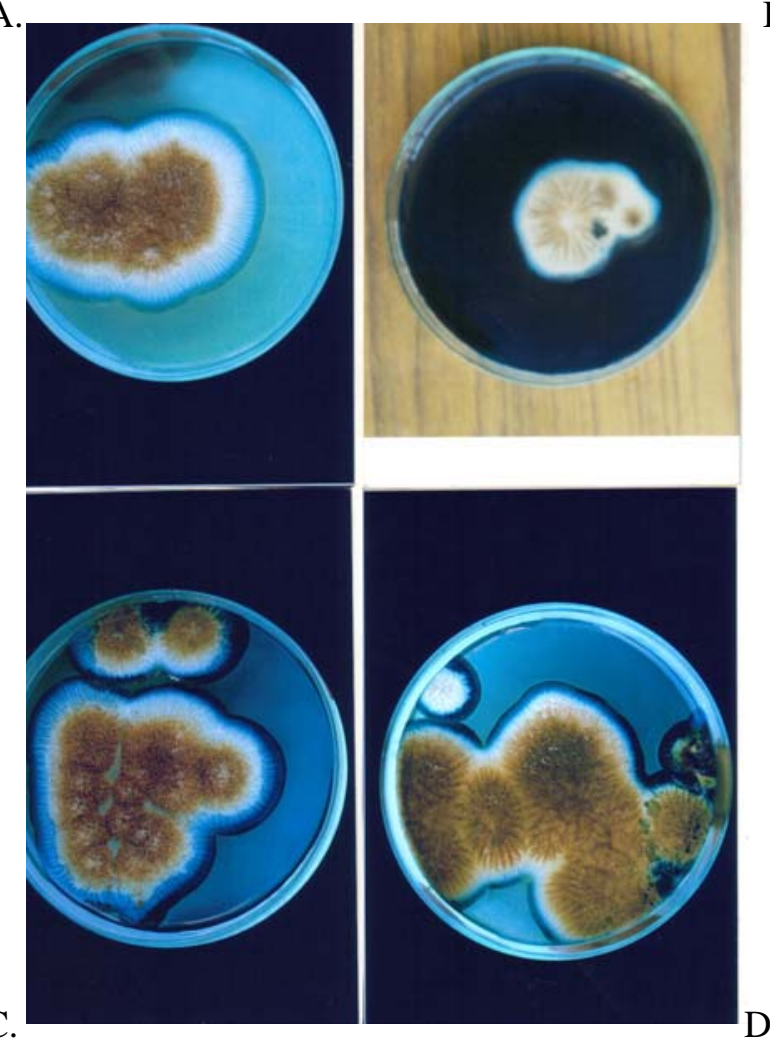

B.

Fig-3-Effect of protein substrates on protease production from Aspergillus tamarii[EF661565.1](A.casein, B.hemoglobin, C. BSA, D. gelatin).

Table1- Effect of Carbon Sources on the Protease Production from Aspergillus tamarii [EF661565.1]. Carbon Source Protease Activity $\mathrm{U} / \mathrm{ml} / \mathrm{min} \pm \mathrm{SD} *$

\begin{tabular}{cc}
\hline Carbon Source & Protease Activity U/mi/min \pm SD* \\
\hline Glucose & $119 \pm 2.5$ \\
\hline Glycerol & $170.3 \pm 1.65$ \\
\hline Tri-Sodium citrate & $119.3 \pm 1.83$ \\
\hline Sucrose & $156.6 \pm 1.58$ \\
\hline Fructose & $106 \pm 1.6$ \\
\hline Starch & $153 \pm 2.16$ \\
\hline
\end{tabular}

*SD-Standard deviation

Table-2- Effect of Nitrogen Sources on the Protease Production from Aspergillus tamarii [EF661565.1].

\begin{tabular}{cc}
\hline Nitrogen Source & Protease Activity U/ml/min \pm SD* \\
\hline Yeast Extract & $236.6 \pm 1.54$ \\
\hline Peptone & $214 \pm 1.63$ \\
\hline Yeast Extract + Glutamic acid & $250 \pm 2.45$ \\
\hline Yeast Extract + Peptone & $219.8 \pm 0.6$ \\
\hline Ammonium sulphate & $169.5 \pm 2.17$ \\
\hline Ammonium nitrate & $179.7 \pm 0.7$ \\
\hline Potassium nitrate & $148.7 \pm 1.56$ \\
\hline
\end{tabular}

*SD-Standard deviation 
Table-3 Purification of Protease from Aspergillus tamarii [EF661565.1].

\begin{tabular}{cccccc}
\hline Purification step & $\begin{array}{l}\text { Total } \\
\text { protease } \\
\text { Activity (U) }\end{array}$ & $\begin{array}{l}\text { Total Protein } \\
(\mathbf{m g})\end{array}$ & $\begin{array}{l}\text { Specific } \\
\text { Activity } \\
\text { (U/mg) }\end{array}$ & $\begin{array}{l}\text { Fold } \\
\text { Purification }\end{array}$ & Yield \% \\
\hline Culture Supernatant & 8839 & 21 & 421 & 1 & 100 \\
\hline $\begin{array}{c}\text { Ammonium sulphate } \\
\text { precipitation and gel } \\
\text { filtration }\end{array}$ & 7543 & 1.9 & 3970 & 9 & 85 \\
\hline CM-Cellulose & 4431 & 0.4 & 11078 & 26 & 50 \\
\hline
\end{tabular}

Table-4 Effect of Different Inhibitors on the Activity of Protease from Aspergillus tamarii[EF661565.1].

\begin{tabular}{cc}
\hline Compound & Relative Activity (\%) \\
\hline Control & 100 \\
\hline pCMB & 91 \\
\hline EDTA & 90 \\
\hline PMSF & 12 \\
\hline$\beta$ Mercatpoethanol & 105 \\
\hline IAA & 100 \\
\hline
\end{tabular}

Table 5- Effect of Various Metal ions on Protease Activity from Aspergillus tamarii [EF661565.1].

\begin{tabular}{cc}
\hline Metal Ions (5 mM) & $\begin{array}{c}\text { Residual Relative } \\
\text { Enzyme Activity (\%) }\end{array}$ \\
\hline Control & 100 \\
\hline $\mathrm{Na}^{+}(\mathrm{NaCl})$ & 85 \\
\hline $\mathrm{Co}^{2+}\left(\mathrm{CoCl}_{2}\right)$ & 75 \\
\hline $\mathrm{Co}^{2+}\left(\mathrm{CaCl}_{2}\right)$ & 60 \\
\hline $\mathrm{Cu}^{2+}\left(\mathrm{CuCl}_{2}\right)$ & 110 \\
\hline $\mathrm{Hg}^{2+}\left(\mathrm{HgCl}_{2}\right)$ & 70 \\
\hline $\mathrm{Zn}^{2+}\left(\mathrm{ZnCl}_{2}\right)$ & 120 \\
\hline $\mathrm{Mg}^{2+}\left(\mathrm{MgCl}_{2}\right)$ & 130 \\
\hline
\end{tabular}

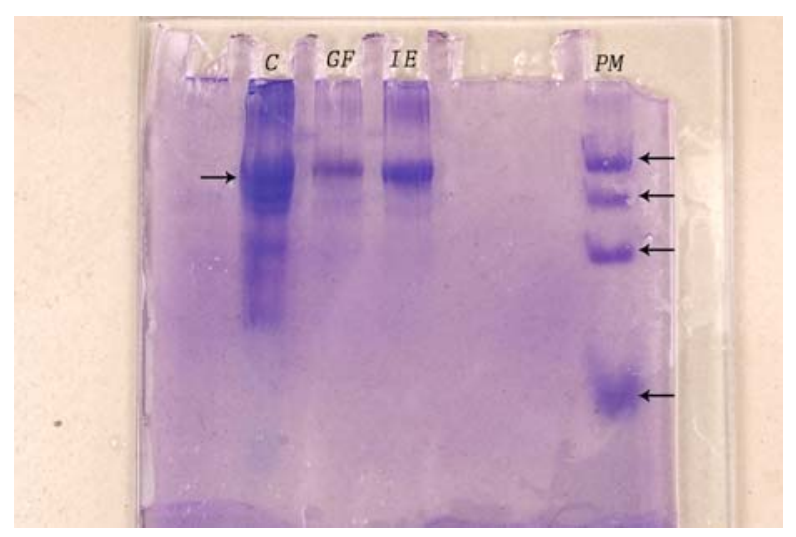

Fig-4: SDS-PAGE of purified alkaline protease from Aspergillus tamarii. Lane PM: Protein molecular mass markers( Bovine serum albumine, 66 kDa; Ovaalbumin,43 kDa;Carbonic anhydrase,29Kda;Lysozyme,14. 3 kDa),Lane IE: Ion exchange fraction showing the monomeric form of purified protease,Lane GF:Gel filtration fraction, Lane C:Crude extract fraction. 
Agric. Biol. J. N. Am., 2011, 2(7): 1135-1142

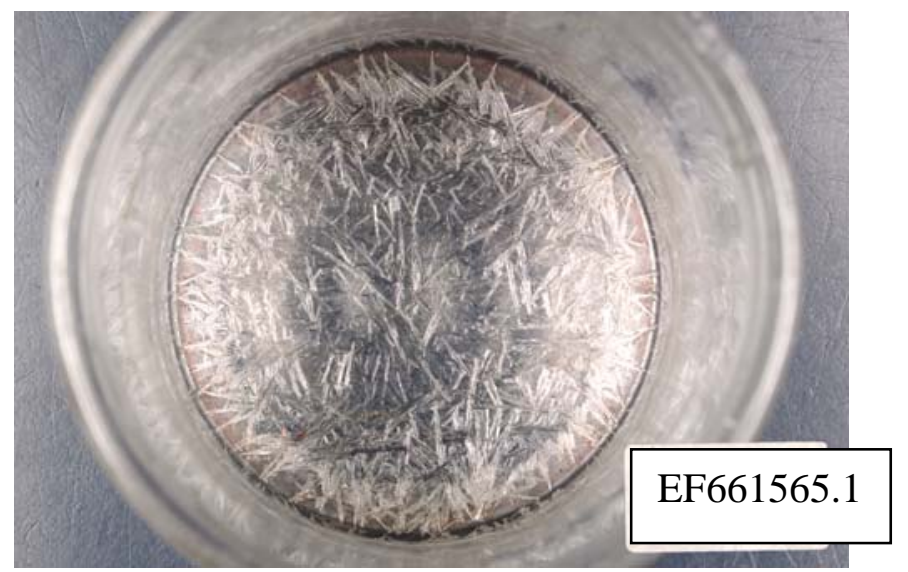

Fig-5: Crystals of purified alkaline protease from Aspergillus tamarii[ EF661565.1].

\section{CONCLUSION:}

In the present study, soil isolate of Aspergillus tamarii [EF661565.1] was shown to exhibit a novel alkaline protease. The alkaline protease was produced on different carbon and nitrogen sources and purified by CM-cellulose chromatography. The crystals of the purified enzyme was obtained by ammonium sulphate. Our future prospect is to improve the crystal formation so that structural features can be studied. On the other hand, its desirable characters, such as, broad range of substrate specificity, high $\mathrm{pH}$ and high temperature of optimum activity are significant properties of this enzyme for industrial application.

\section{ACKNOWLEDGEMENT:}

The authors are very thankful to Agharkar Research Institute, Pune, India for providing their services in molecular identification of fungal sample.

\section{REFERENCES}

Aleksieva, P., Djerova, A., Tchorbanov, B and Girarov, J (1981). Submerged cultivation of a strain of Humicola lutea 72 producing acid protease, Eur. J. App. Microbiol, Biotechnol, 13 :165-169.

Anson, M.L. (1938) .The estimation of pepsin , trypsin, papain and cathepsin with hemoglobin, J. Gen. Physiol,22:79-89.

Celia, R., Tremacoldi and Eleonora, C.C, (2007). Production of extracellular alkaline protease by Aspergillus clavatus, World J. of Microbiology and Biotechnology, 21:169-172.
Cervosky, V (1992). Protease catalyzed peptide synthesis in solvent - free system, Biotechnol, Techniques, 6: $155-160$.

Chakrabarti, S.K., Matsumura, N and Ranu R.S, (2000). Purification and characterization of an extracellular alkaline serine protease from $A$. terreus, Curr Microbiol, 40: 239-244.

Charles,P., Devnathan, V., Periasamy A., Kalaichelvan, P.T., and Hur, B.K. (2008). Purification, characterization and crystallization of an extracellular alkaline protease from Aspergillus nidulans HA-10, Journal of basic microbiology, 48:347-352.

de Gorgi, GS., de Valdez, G.F., de Ruiz Itolgada, A.P and Oliver, G, (1985). Effect of $\mathrm{pH}$ and temperature on the proteolytic activity of lactic acid bacteria.J. J. Dairy Sci., 68: 2160-2164.

Fujiwara, N., Yamamoto, K. and Masui, A. (1991). Utilization of a thermostable alkaline protease from an alkalophilic thermophile for the recovery of silver from used X-ray film, J. Ferment Bio eng, 72: 306-308.

Gajju, H., Bhalla, T.C and Agarwal, H.O. (1996). Thermostable alkaline protease from thermophilic Bacillus coagulans PB-77, Ind.J. Microbiol, 36: 153155.

Gessesso, A., Kabul, R.H., Gashe, B..A and Mattiasson, B, (2003) . Novel alkaline protease from alkalophilic bacteria grown on chicken feather, Enzyme Microbiol. Technol 32: 519-524.

Glazer, A.G and Nikaido, H. (1995). Microbial, Biotechnology: Fundamental of applied Microbiology, Freeman and Company, Washington: 256-259.

Gold, A.M and Fahrney, (1964). Salfonylfluorides as inhibitors of esterases 11 Formation and reactions of 
phenylmethane sulfonyl alpha - chymotrypsin. Biochem. 3 : 783-791

Hayashi, K., Terada, M and Moki, K, (1970). Reinvestigation of Molecular weight and terminal amino acid residues of alkaline proteinase from Aspergillus sojae, Agri-Biol. chem.: 34:289-295.

Hossain, M.T., Das, F.,Marzan, L.W., Rahman, M.S and Anwar, M.N, (2006) . Some properties of protease of the fungal strain Aspergillus flavus Int, J Agric biol. 8(2): $162-164$

Jaswal, R.K and Kocher, G.D (2007). Partial characterization of a crude alkaline protease from Bacillus circulans and its detergent compatibility, The internet J. of Microbiology; 4(1).

Joo, H.S., Kuma, C.G., Park, C.G., Paik, S.R and Chang C.S (2003) . Oxidant and SDS stable alkaline protease from Bacillus clausii 1-52 : Production and some properties, J. Appl. Microbiol, 95: 265-272.

Kazan, D., Denizei, A.A., Kerimak onu, M.N and Erarslan, A (2005). Purification and characterization of a serine alkaline protease from Bacillus clausis GMBAE 42, J.Ind. Microbiol and Biotechnol, 32: 335-344.

Kim, J..M., Yang, M.C and Hung J.S (2005). Preparation of feather digest as fertilizer with Bacillus pumillus KHS-1, J. Microbiol, Biotechnol, 15: 427-476.

Lowry O.H., Rosebrough N.J., Farr AL and Randall R.J, (1951). Protein measurement with Folin phenol reagent, J Biol Chem, 193: 265-275.

Lin, An-Na Ai-Yun Ding Jing, Shou-AnLia; Ming Zhang and Duo-Chuan Li, (2007). Purification and characterization of two thermostable proteases from the thermophilic fungus Chaetomium thermophilum, $\mathrm{J}$. Microbiol, Biotechnol; 17(4) :624-631.

Miyaji, T., Otta, Y.,Nakagawa, T., Watanabe, T., Niimura, Y and Tomizuka, N (2006). Purification and molecular characterization of subtilisin like alkaline protease BPP-A from Bacillus pumillus strain MS, J. Lett. ApplMicrobiol; 42: 242-247.

Outrup, H., and COL Boye, (1990). Microbial proteinases and biotechnology. In Fogarty, W.M. (ed), Microbial enzymes and biotechnology, $2^{\text {nd }} E d$, London and New York, Elsevier Science Publisher.

Phadatare, S.U., Deshpande, V.V and Srinivasan, M.C (1993). High activity alkaline protease from
Condiobolus Coronatus (NCL 86.8.20): enzyme production and compability with commercial detergents. Enz. Microb. Technol; 15: 72-76.

Prasad R.S., Malik PK., and Mathur D.K (1984). Optimization of nutritional and environmental factors for the production of caseinolytic enzyme of Micrococcus sp. isolated from cheddar cheese..Asian J. Dairy Res, 3: 25-36.

Sandhya, C., Sumantha, A., Szakacs, G and Pandey, A (2005). Comparative evaluation of neutral protease production by Aspergillus oryzae in submerged and solid state fermentation. Process Biochem 40: 26892694.

Sen, S and Satyanarayana, T (1993). Optimization of alkaline protease production by thermophilic Bacillus licheniformis S-40, Ind. J. Microbiol, 33 :43-47.

Sharma, J., Singh, A., Rajesh, K., and Mittal, A (2006). Partial purification of an alkaline protease from a new strain of Aspergillus oryzae AWT20 and its enhanced stabilization in entrapped Ca-alginate beads, The internet J. of Microbiology 2(2).

Sinha, N and Satyanarayana, T (1991). Alkaline protease by thermophilic Bacillus licheniformis. Ind. J. Microbiol, 31: 425- 430.

Tunga, R., Shrivastava, B., and Banerjee, R, (2003). Purification and characterization of a protease from solid state cultures of $A$. parasiticus. Process Biochem, 32: 1553-1558.

Turkova, J., Mikes, O., Richou, R and Lallouette P, (1971). Biochemical and immunological properties of an alkaline protease extracted from $A$. flavus. Rev. Immunol. (Paris), 35 :149-157

Vermelho, BA., Meirelles, M.N., Lopes, A., Petinate, S., Chaia A.A and Branquinha, M.H (1996). Detection of extracellular protease from Microorganisms on agar plates, Mem. Inst. Oswaldo cruz, Rio de Janerio, 91(6) :755-760.

Ward, O. P(1983). Protease, In Fogarty, WM (ed) ,Microbial enzymes in Biotechnology, London Applied Science Publisher.

Wellingta CAN and Meire LLM, (2004). Production and properties of an extracellular protease from thermophilic Bacillus, sp. Braz. J. Microbiol. 35 : 1-2. 